\title{
A STUDY ON THE FACTORS INFLUENCING YOUNG MUSLIMS' BEHAVIORAL INTENTION IN CONSUMING HALAL FOOD IN MALAYSIA
}

\author{
Aiedah Abdul Khalek ${ }^{1}$ \\ Sharifah Hayaati Syed Ismail ${ }^{2}$ \\ Hairunnisa Mohamad Ibrahim ${ }^{3}$
}

\begin{abstract}
This study aims to identify the factors that influence young Muslims' behavioral intention to consume halal food in the Malaysian Private Higher Learning Institutions. Ajzen's Theory of Planned Behavior (TPB), adapted as a theoretical framework postulates three components which are attitude, subjective norms and behavioral control of consumers. Data were collected through self-administered questionnaires using a 5 point Likert Scale. The respondents are young Malaysian Muslim consumers between the ages of 16 and 35 years. The findings of this study show the intention to consume halal food in Klang Valley, Malaysia is predominantly influenced by young Muslims' positive attitudes and their behavioral control towards halal food. The factor of subjective norms is found to have no
\end{abstract}

1 PhD Candidate, Department of Siasah Syar'iyyah, Academy of Islamic Studies, University of Malaya, dejana2000@yahoo.com

2 Associate Professor, Department of Siasah Syar'iyyah, Academy of Islamic Studies, University of Malaya, sashsiaq@um.edu.my

3 Lecturer, School of Hospitality, Tourism and Culinary Arts, Taylors University, Malaysia, Hairunnisa.MohamadIbrahim@taylors.edu.my 
significant influence as compared to the attitude and behavioral control of young Muslims' behavioral intention in consuming halal food in Malaysia. The respondents were from higher learning institutions in Klang Valley. Therefore, future research may broaden the sample size and expand the geographical areas to other states in Malaysia. Future research also may look into the influence of behavioral control and subjective norms towards the attitude of young consumers in choosing halal food and other products. This study contributes and extends knowledge of the Muslim consumers' behaviors in consuming halal food. The findings provide information to the manufacturers in expanding their market and for governmental agencies and associations to promote halal food consumption.

Keywords: Muslim consumers' behavior, halal food, Higher Learning Institution

\section{INTRODUCTION}

Halal industry is regarded as a global and fast developing industry in the world market. It is reported that 60 percent the annual global market value of the entire halal trade, which is estimated at USD 2.3 trillion, is generated from halal food. ${ }^{4}$ Malaysia has aimed to become the global halal hub, thus planning to significantly contribute to the economic growth of the country.

In Malaysia, halal market is supported by the Malaysian Halal Master Plan introduced in 2008 covering the halal integrity, implementation consumption and services, the Third Industrial Master Plan (IMP3, 2006-2020) and the Tenth Malaysia Plan (2010-2015). In addition, the institutionalization of Halal Industry Development Cooperation (HDC), has added the prominence of halal industry in Malaysia. ${ }^{5}$ HDC in particular, manages the general development of the Halal industry, including encouraging business involvement and consumers' awareness in this industry. ${ }^{6}$ Furthermore, the Malaysian government has

$4 \quad$ Halal Industry Development Corporation, 'Market Information,' website HDC, http://www.hdcglobal.com/publisher/bhi_market_information\#synopsis, 31 December 2012.

5 Johan Fischer, 'Religion, Science and Markets,' EMBO Report 9/9 (2008): 829830.

6 Halal Industry Development Corporation, www.hdcglobal.com/publisher/about, 11 January 2012. 
allotted a yearly budget every year in order to develop long term and short term planning to boost the development of halal industry.

Department of Islamic Development Malaysia (JAKIM) is assigned as the main authority in halal certification. The halal certification issued by JAKIM is benefits the manufacturers and food operators, as an assurance that their food or products are halal compliant and can be regarded as a benchmark for safety and quality assurance to consumers. Therefore, halal certification is crucial in building consumers' confidence in the halal food that they consume and could be viewed as a powerful marketing tool. ${ }^{8}$ Similarly, in United Arab Emirates, $86.5 \%$ of Muslim consumers looked for the halal certification before they purchased products or services. ${ }^{9}$

Technically, halal food ought to be prepared, processed and manufactured hygienically, thus it is safe for human consumption. These include the process of slaughtering, storing, displaying and preparing of the food. ${ }^{10}$ Yūsuf alQaraḍāwī conceptualizes the concept of halal as lawful and permissible, which technically refers to the food permitted by Allah SWT and no restriction from any reliable sources in Islam. ${ }^{11}$ The word halal is mentioned together with the word "tayyib" several times in the Quran. "Tayyib" is an Arabic word which means pure, wholesome and of good quality. ${ }^{12}$ It reflects the characteristic of halal where food should be wholesome, possess good quality and not harm consumers. ${ }^{13}$

7 Zalina Zakaria, 'Tapping Into the World Halal Market: Some Discussions on Malaysian Laws and Standard,' Shariah Journal 16 (2008): 610.

8 Hakimah Mohd Yusoff, 'Industry Standards Committee on Halal Standards (ISCI),' Standard and Quality News 11/4 (2004): 4-5.

9 Wilson, J.A., \& Liu, J., 'The Challenges of Islamic Branding: Navigating Emotions and Halal,' Journal of Islamic Marketing 2/1 (2011): 28.

10 Shahidan Shafie, Md Nor Othman, 'Halal Certification: An International Marketing Issues and Challenges: Malaysia Standardization for Halal Food,' Standard and Quality News 11/4 (2004): 9.

11 Yūsuf al-Qaraḍāwī, al-Halāl wa al-Harām fì al-Islām, 15 ${ }^{\text {th }}$ ed. (Qāhirah: al-Maktāb al-Islāmī, 1994), 17.

12 Anas Mohd Yunus, Wan Mohd Yusof Wan Chik, Mahani Mohamad, 'The Concept of Halalan Tayyiba and Its Application in Products Marketing: A Case Study at Sabasun HyperRuncit Kuala Terengganu, Malaysia,' International Journal of Business and Social Science 3 (2010): 243.

13 Ahmad Azrin Adnan, 'Islamic Consumer Behavior (ICB): Its Why and What,' International Journal of Business and Social Science 2/21 (2011): 157. 


\section{OBJECTIVES AND RESEARCH QUESTIONS}

This study aims to identify the factors which influence young Muslims' behavioral intention to consume halal food in Malaysia. Therefore, the primary research question of this study is: What are the factors that influence young consumers to consume halal food in Malaysia? Specifically, this study examines the factors based on three variables of Theory of Planned Behavior (TPB); attitude, subjective norms and behavioral control and how they are related to the behavioral intention of young consumers in choosing halal food in Malaysia.

\section{LITERATURE REVIEW}

Generally, consumers' intention and behaviour are influenced by their religion. ${ }^{14}$ Religion was established as an important factor in deciding food purchasing and developing food habits of individuals and societies. The influence of religion on food consumption is closely related to the religious teaching and people's interpretation of the religion itself. From Islamic point of view, the food dietary regulation on halal food is prescribed in the book of al-Quran and al-Sunnah, the practice of Prophet Muhammad. Al-Quran as the holy book for Muslims mentioned many times about halal food consumption. For example, in surah al-Mā'idah verses 87-88;

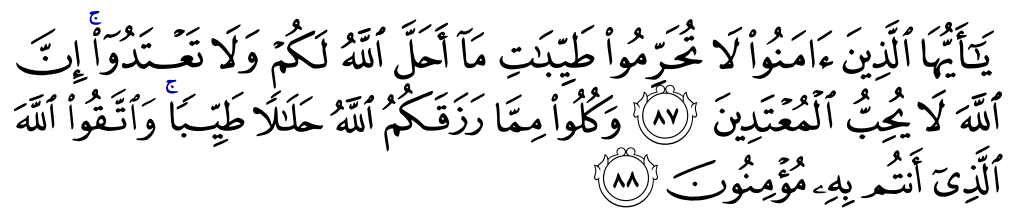

"You who believe! Do not make haram the good things which Allah has made halal for you, and do not transgress; indeed, Allah does not like the transgressors. And eat of what Allah has provided for you, lawful and good, and fear Allah, in whom you are believers.."

(Surah al-Mā'idah, 5: 87-88)

Food consumption is generally related to attitude, social pressure and behavioral control of the individual. In addition, social structure such as people's origin and generation differences also play a part in predicting

14 Delener, Nejdet, 'Religious Contrasts in Consumer Decision Behaviour Patterns: Their Dimensions and Marketing Implications,' European Journal of Marketing, 28/5 (1994): 36. 
dietary preferences of consumers. ${ }^{15}$ Golnaz et al. (2009) studied the concern of halal labeled food products among Muslim consumers by considering the demographic factors; for example religiosity, educational background and the state of origin in Malaysia. ${ }^{16}$ In this study, external variables were adapted to Theory of Planned Behavior (TPB) in determining the concerns of Muslims on halal labeled food products. Data collected revealed that religiosity and education positively related to the awareness among Muslims to consume food products with halal labeled products.

It was found that attitude and perceived behavioral control strongly influenced Muslims' behavioral intention to choose halal food. However, social influence was not as strong as attitude and perceived behavior control of Muslim consumers. In relation to the influence of education, formal and informal religious education were found as to be essential in determining halal food consumption among Muslims. As such, Muslims who acquired religious education formally in religious school were more concerned about halal food consumption compared to those who did not receive formal religious education. ${ }^{17}$

The Theory of Planned Behavior (TPB) was used in a number of studies related to consumers' behavior and social psychology. Several studies on halal food consumption used TPB as their theoretical framework in determining consumers' intention to purchase and consume halal food and products. A study conducted by Syed Shah Alam and Nazura (2011) demonstrated that attitude, subjective norms and behavioral control have significant impact on intention to purchase halal food. ${ }^{18} \mathrm{Zul}$ Ariff Abdul Latiff et al. (2012) included

15 Karijn Bonne, Iris Vermeir, Florence Bergeaud-Blackler, Wim Verbeke, 'Determinants of Halal Meat Consumption in France,' British Food Journal 109/5 (2007): 379.

16 Golnaz, R., Zainalabidin, M., Mad Nasir, S. and Eddie Chiew, 'Concerns for Halal Labeled Food Products Among Muslims Consumers in Malaysia: Evaluation of Selected Demographic Factors,' Economic and Technology Management Review 4 (2009): 65.

17 Endang S Soesilowati, 'Business Opportunities for Halal Products in the Global Market: Muslim Consumer Behaviour and Halal Food Consumption,' Journal of Indonesian Social Sciences and Humanities 3 (2010): 158.

18 Syed Shah Alam and Nazura Mohamed Sayuti, 'Applying the Theory of Planned Behavior (TPB) in Halal Food Purchasing,' International Journal of Commerce and Management 21/1 (2011): 16. 
labeling and halal logo as determinants in predicting halal consumption in Malaysia. ${ }^{19}$

Using the TPB as a conceptual framework, Liou and Contento (2001) reveal that a subjective norm was not significant towards food behavioral intention in Chinese American Society. ${ }^{20}$ In contrast Sudin Lada et al. (2009) and Arshia and Mohsin (2012), found that attitude and subjective norms were positively related to the intention of choosing halal products among consumers. ${ }^{21}$ In addition to that, Sudin Lada et al. (2009) argued that subjective norms played the most important influences of halal food consumption in a multiracial society. ${ }^{22}$

Data collected from the study by Abdul Raufu Ambali and Ahmad Naqiuddin Bakar (2010) demonstrated that food labeling, including halal logo influenced their purchasing behavior. Another study showed that religious belief, exposure, logo certification, and health reasons were determinants in predicting halal awareness among Muslims. Interestingly, health reason was the most significant factor that contributed to the awareness among Muslims on halal food and products. ${ }^{23}$

In addition, halal branding was also used to attract Muslim consumers. Wilson and Liu (2010) argued that the role of halal branding is substantial in attracting Muslim consumers such as the use of terms like "Halal Insurance", "Halal Finance" in banking and finance industry. This can also be applied in the context of Malaysia, where halal branding is very common in influencing

19 Zul Ariff Abdul Latiff, Zainal Abidin Mohamed, Golnaz, R., Nitty Hirawaty Kararuzzaman, 'The Effect of Food Labeling Awareness on Muslim Consumers Food Purchasing Behavior in Malaysia,' Proceeding of International Halal Conference (Kuala Lumpur: Putra World Trade Centre, 11-12 September 2012), 806.

20 Liou, D. and Contento, I.R., 'Usefulness of Psychosocial Theory of Variables in Explaining Fat-Related Dietary Behaviour in Chinese American: Association with Degree of Acculturation,' Journal of Nutrition Education 33/6 (2001): 322.

21 Sudin Lada, Geoffrey Harvey Tanakijal, Hainudin Amin, 'Predicting Intention to Choose Halal Products Using Theory of Reasoned Action,' International Journal of Islamic and Middle Eastern Finance and Management 2/1 (2009): 66-76; Arshia, M. and Mohsin, M.B, 'Intention to Choose Halal Products: The Role of Religiosity,' Journal of Islamic Marketing 31 (2012): 1-11.

22 Sudin Lada, Geoffrey Harvey Tanakijal, Hainudin Amin, 'Predicting Intention to Choose Halal Products Using Theory of Reasoned Action,' 66-76.

23 Abdul Raufu Ambali and Ahmad Naqiuddin Bakar, 'People's Awareness on Halal and Products,' Proceeding of International Halal Conference (Kuala Lumpur: Putra World Trade Centre, 11-12 September 2012), 744. 
Muslim consumers to purchase products and services such as "ḥalālan țayyiban food" and "halal tour." 24

Earlier research did not emphasize on the factors that influence young consumers' behavioral intention to consume halal food in Malaysia. Research has shown that young consumers have different patterns of behavior compared to the older generation. They are heavier consumers, knowledge-based in their choices, brand conscious and trendsetters. Thus, the findings of behavioral intentions of halal consumption conducted with older respondents should not be generalized to the younger generation due to their unique consumption behavior and preferences. In fact, research on young Muslim consumers has substantially revealed that they are the largest and most lucrative consumers particularly on food consumption. ${ }^{25}$

Halal is a broad topic and could be discussed from many perspectives and disciplines. However, there has been a lack of empirical data on halal particularly from cross disciplinary sources. ${ }^{26}$ Thus, this study attempts to contribute to the body of knowledge by providing empirical data on halal consumption from the perspectives of young Muslim consumers living in Malaysia.

\section{METHODOLOGICAL APPROACH}

This study used quantitative survey method to collect data from Muslim consumers. It was found that quantitative survey method was widely used in testing the Theory of Planned Behavior by established researchers in the field of halal consumption, for example, Syed Shah Alam and Nazura (2011), Golnaz et al. (2010), Bonne et al. (2007) and Bonne and Verbeke (2006). Hence, data were analysed using the Statistical Package of Social Sciences (SPSS). Descriptive analysis, correlation, chi-square and multiple regression tests were employed in order to answer the research questions and to achieve the objectives of this study.

\footnotetext{
${ }_{24}$ Wilson, J.A., Liu, J., 'Shaping The Halal Into A Brand?' Journal of Islamic Marketing 1/2 (2010): 111.

25 Kristen M. Regine, Johnson \& Wales University, 'Generation Y Consumer Choice for Organic Foods,' Journal of Global Business Management 7/1 (2011): 2-3.

26 Wilson, J.A., Liu, J., 'Shaping The Halal Into A Brand?' 107.
} 


\section{INSTRUMENT}

The instruments were established by the researchers based on the TPB which consists of three constructs; attitude, subjective norms and perceived behavioral control. The guidelines for constructing a questionnaire recommended by its pioneer Ajzen Izek items was used to develop the instrument. ${ }^{27}$

The first section of the questionnaire encompassed demographic information such as age, gender, level of education, formal and non-formal knowledge about halal. The attitude was measured by 8 items of the favorable and nonfavorable respondents' evaluation of halal food as below;
a. Eating halal food is important for me.
b. I prefer to consume halal food compared to non-halal food.
c. Halal food is clean.
d. Halal food is cleaner compared to non halal food.
e. Halal food is safe to eat.
f. Halal food is safer to eat compared to non halal food.
g. Halal food is healthy.
h. Halal food is healthier compared to non-halal food.

The measurement of subjective norms consisted of 5 items as listed below;
a. Most people who are important to me are choosing halal food.
b. People can influence me to eat halal food.
c. My family members prefer halal food.
d. My friends would think that I should choose halal food.
e. My family imposes on me the importance of eating halal food.

Perceived behavioral control variable was tested using 5 items as listed below;
a. It is easy to find halal food in Malaysia
b. It is easy to find halal food in my University.
c. I always have a chance to eat halal food.
d. There are many choices of halal food in my University.
e. Price of halal food is reasonable.

The last section of the questionnaire comprising of 7 items on the behavioral intention in consuming halal food is listed below;

27 Ajzen I., 'Constructing A Theory of Planned Behavior Questionnaire,' retrieved online with author permission from http://www.people.umass.edu/aizen on 9 September 2011, 1. 
a. I will not eat if the food is non-halal.

b. I will not eat if the food is doubted as halal.

c. I will eat only in halal food outlets.

d. I will eat only halal food.

e. I will make sure that the food is halal before I consume it.

f. I will make sure that the food is halal before I purchase it.

g. I will not consume the food if it is prepared using any non-halal ingredients for example alcohol.

A five point Likert scale was used to measure the constructs, ranging from "strongly disagree (1)" to "strongly agree (5)". The questionnaires were pretested by 10 young consumers and 3 scholars in the field, in order to ensure its validity. Based on the comments from the scholars, few amendments were made to the instrument. Prior to the actual survey, a pilot study was done with 50 consumers. Factor analysis was conducted in order to ensure the internal consistency of measurement items by using principal component analysis. An eigenvalue of more than one was used to determine the criteria for each factor in factor analysis. The result of factor analysis showed that each instrument exceeded 0.6, which met the essentially significant level of convergent validity.

The reliability of the items in this study was confirmed by computing the Cronbach's alpha. Nunnally (1978) recommended a minimum alpha 0.7 for basic research reliability. ${ }^{28}$ Table 1 shows the Cronbach's alpha projected scale each variable reaches the minimum alpha of 0.7 . Therefore, the reliability of the constructs was considered acceptable for this study.

Table 1 : Reliability Coefficient

\begin{tabular}{lccc}
\hline Variables & $\begin{array}{c}\text { Number of } \\
\text { Items }\end{array}$ & Items Dropped & Cronbach $\boldsymbol{\alpha}$ \\
\hline Attitude & 14 & - & 0.754 \\
Subjective Norm & 5 & - & 0.699 \\
Behavioral Control & 5 & - & 0.852 \\
Behavioral Intention & 3 & - & 0.719 \\
\hline
\end{tabular}

Source: Questionnaire, Klang Valley, 1-30 April 2012.

28 Nunally J.C \& Berstein Ira. H., Psychometric Theory, $2^{\text {nd }}$ ed. (New York: McGrawHill, Inc., 1978), 245. 


\section{DATA COLLECTION}

A random sample of young Muslim consumers was drawn upon from 5 higher learning institutions in Klang Valley. Young consumers are defined as consumers between ages 16-35. Age, religion and education level of homogeneous sample were used since the objective of this study is to identify the factors influencing young Muslims' to consume halal food in Malaysia. Young people are important as they constitute the larger number of consumers who are more confident to try new food and eat out frequently compared to older consumers. 50 respondents were randomly chosen to complete the pilot test. 300 questionnaires were distributed to undergraduate students and a total of 255 questionnaires were completed by the respondents.

\section{THEORETICAL FRAMEWORK}

A number of frameworks were proposed to elucidate consumers' behavior towards food. ${ }^{29}$ However, TPB and TRA were among the two prominent frameworks used in explaining reasons why Muslim consumers choose halal food and products. TRA presented two determinant variables; attitude and subjective norms. ${ }^{30}$ In addition to TRA's variables, TPB included behavioral control as another determinant in predicting consumers' behavioral intention. The main ideas of TPB and TRA theories are the individual behaviors as guided by his/her behavioral intention. The importance of behavioral intention in engaging behavior was researched and discussed by many scholars. It was found that the stronger the intention to perform a behavior, the more likely the behavior will be performed. ${ }^{31}$

Therefore TPB was adopted in this study not only because it was proven effective in predicting consumers' behavior towards halal food, ${ }^{32}$ but also because it incorporated behavioral control as one of the variables in determining consumers' behavioral intention, particularly Muslims in choosing halal food.

29 Sparks, P. and Sheperd, R., 'Self Identity and the Theory of Planned Behavior: Assessing the Role of Identification with Green Consumerism,' Social Psychology Quarterly 55/4 (1992): 388.

30 Lutz, R.J, 'The Role of Attitude Theory in Marketing,' in Perspectives in Consumer Behavior, ed. Kassarjian, H.H. and Roberson, T.S. (Englewood, Prentice Hall, 1991), 233.

31 Ajzen I., 'The Theory of Planned Behavior,' Organizational Behavior and Human Decision Processes 50 (1991), 181.

32 Syed Shah Alam and Nazura Mohamed Sayuti, 'Applying the Theory of Planned Behavior (TPB) in Halal Food Purchasing,' 17. 
This view was supported by Armitage and Corner (2001) who mentioned that perceived behavioral control was often found as a good predictor of behavior. ${ }^{33}$

As highlighted by Ajzen, many other social scientists stressed on the importance of behavioral intention in predicting the behavior of individuals and society. Indeed the importance of behavioral intention in predicting human behavior was adopted in many research studies across the academic fields. Ajzen (2006) stressed that determinants influencing behavioral intention are belief of a human being about the possible consequences of the behavior, beliefs about the normative expectations of others, and beliefs about the presence of factors that may encourage or obstruct the behavior. ${ }^{34}$

The importance of behavioral intention is likewise highlighted in the teaching of Islam. In fact, every human action either 'ibādah or daily activities should begin with a good niyat (intention). Few ulamā' for example Ibnu Qayyim and Imām al-Ghazzālī supported this opinion. ${ }^{35}$ Islam as a way of life provides comprehensive guidelines in daily human actions for example actions like eating, drinking, exercising and sleeping. ${ }^{36}$ This view is closely related to food consumption, which is a daily life activity that could be turned to good deeds if accompanied by a niyat (intention) for the sake of Allah SWT. However, in the context of halal food consumption, choosing halal food is compulsory and eating haram food is forbidden for Muslims.

The importance of behavioral intention was stressed many times in alQuran. It is noted that the behaviors of mankind are based on their intentions. Allah SWT mentioned in the al-Quran in surah al-Zumar, verse 11:

33 Armitage, C.J., and Conner, M., 'Efficacy of the Theory of Planned Behavior: A Meta-Analytic Review,' British Journal of Social Psychology 40 (2001): 471.

34 Ajzen I., 'Constructing A Theory of Planned Behavior Questionnaire,' retrieved online with author permission from http://www.people.umass.edu/aizen, 16 April 2013, 1.

35 Rushdi Ramli, 'Nilai Ibadat dalam Perbuatan-Perbuatan Harus (al-Af'āl alMubāḥah): Tinjauan Terhadap Pemikiran Imām Aḥmad Ibn Taymiyyah,' Jurnal Fiqh 7 (2010): 154.

36 Rushdi Ramli, 'Nilai Ibadat dalam Perbuatan-Perbuatan Harus (al-Af'āl alMubāḥah): Tinjauan Terhadap Pemikiran Imām Aḥmad Ibn Taymiyyah,’ 165. 


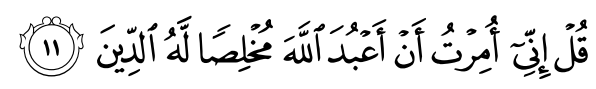

"Say (O Muhammad): Verily, I am commanded to worship Allah (alone) by obeying Him and doing religious deeds sincerely for His sake only."

(Surah al-Zumar, 39: 11)

Hence, it is observed that the role of behavioral intention in performing human behavior as discussed by current social scientist, particularly Ajzen the founder of TPB and TRA theories is not something new in Islamic teaching. In fact, the concept and application of behavioral intention is reflected in the main sources of Islam; the al-Quran and al-Sunnah. The importance of behavioral intention indeed was highlighted in performing ibādah and daily activities. In addition, the TPB is not contradicted with the Islamic teaching and it has supported the concept of niyat (intention) as prescribed in Islam.

In conceptualizing the factors influencing halal food consumption in this research, attitude towards behavior refers to the respondents' favorable or unfavorable evaluation to consume halal food. Secondly, a subjective norm is a perceived social pressure for young consumers to consume halal or non halal food. The third determinant is perceived behavioral control defined as a belief about individual control of the opportunities and availability of halal food in Malaysia. The research model used in this study is also based on the TPB as shown in Figure 1.

Figure 1: A Schematic Diagram of TPB.

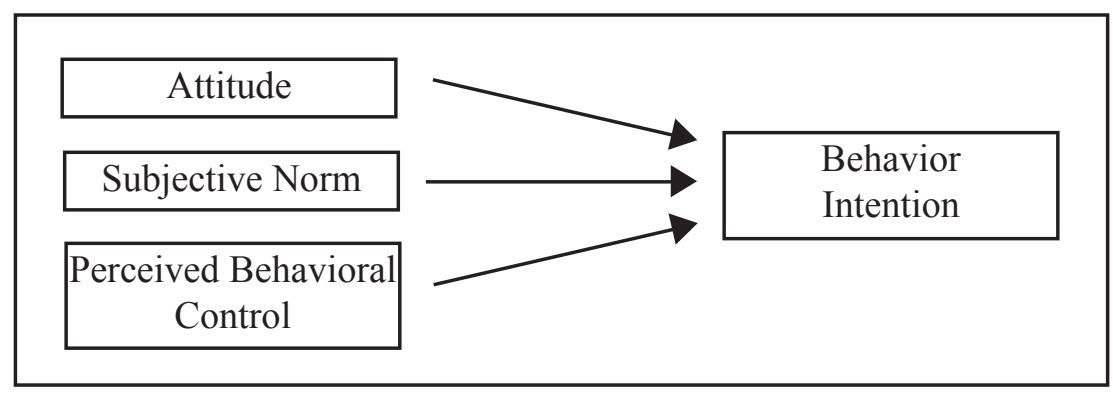

Source: Ajzen Icek \& Fishbein Martin (1991). ${ }^{37}$

The framework shows that attitude, subjective norms and perceived behavioral control have certain influence towards behavioral intention and

$37 \quad$ Ajzen Icek and Fishbein Martin, Understanding Attitude and Predicting Social Behavior (Eaglewood-Cliffs, New Jersey: Prentice Hall, 1991), 179. 
in this study; towards Muslims' intention in choosing halal food. Hence, the framework yields the following hypotheses:

H1: There is a positive relationship between the attitude of young consumers and the intention in choosing halal food.

Attitude has an influence towards the behavioral intention, and in the context of this research towards Muslims' intention in choosing halal food. In addition, attitude could be religious-based evaluation on the importance of eating halal food for Muslims. As Bonne (2006) indicated, Muslims eat halal food to abide the teaching of Islam. ${ }^{38}$

$\mathrm{H} 2$ : There is a positive relationship between subjective norms of young consumers and the intention in choosing halal food.

In general, human behavior was influenced by the expectations of others, such as friends, family and societal norms. ${ }^{39}$ As a predominantly Muslim country, Malaysia is apparent as a collectivistic society where people perceive themselves as interdependent with their society and the expectations of others in the society are important to them.

H3: There is a positive relationship between perceived behavioral controls of young consumers and their intention in choosing halal food.

According to Ajzen (1991) perceived behavioral control could contribute to the prediction of behavior. In this study, perceived behavioral control is referred as the perceived control of consumers in consuming halal food. ${ }^{40}$

\section{FINDINGS}

Descriptive analysis, regression and correlation methods were used to explain the relationship between dependent and independent variables in this study.

38 Karijn Bonne, Iris Vermeir, Florence Bergeaud-Blackler, Wim Verbeke, 'Determinants of Halal Meat Consumption in France,' British Food Journal 109 (2007): 379.

39 Van Hooft, E.A.J., Born, M.Ph., Taris, T.W. and Van Der Flier, H., 'The CrossCultural Generalizability of the Theory of Planned Behavior: A Study on Job Seeking in the Netherlands,' Journal of Cross-Cultural Psychology 37/2 (2006): 135.

40 Ajzen, I., 'Attitude and Structure and Behavior,' in Attitude Structure Function, ed. A.R. Pratkanis, S.J. Breckler and A.G. Greenward (Hilladale, New-Jersey: Erbaum, 1989), 241. 
The findings of this study present the influence of three independent variables; attitude, subjective norms and perceived behavioral control of young Muslim consumers to their behavioral intentions in consuming halal food.

\section{CHARACTERISTICS OF THE RESPONDENTS}

Descriptive analysis was used to analyze the demographic information of the respondents such as gender, age, education, origin, formal knowledge about halal food and non formal knowledge about halal food. Table 2 shows the profile of respondents. 140 respondents were female $(54.9 \%)$ and $115(45.1 \%)$ were male. About three-quarters of the respondents $(77.3 \%)$ were between 1928 years old. 225 respondents $(88 \%)$ were Malaysians and the remaining from other countries. The respondents for formal knowledge about halal food was acquired from fardhu ain class, primary school, secondary school, college and university. It was found that the majority of the respondents $(45.9 \%)$ acquired formal knowledge about halal food in fardhu ain class (KAFA). Non formal knowledge about halal food was attained through internet $(22.7 \%)$, family $(27.8 \%)$, books $(14.5 \%)$, magazines $(9.8 \%)$, television $(5.1 \%)$, friends $(3.9 \%)$, and radio $(2.7 \%)$. 
Table 2: Demographic Profile Respondents $(n=255)$.

\begin{tabular}{|c|c|c|c|}
\hline Characteristics & Percentage (\%) & Frequency & Percentage (\%) \\
\hline Gender & & Formal Knowledge & \\
\hline Female & 54.9 & about Halal Food & \\
\hline Male & 45.1 & Fardhu Ain Class (KAFA) & 45.9 \\
\hline Age & & Primary school & 26.3 \\
\hline $16-18$ years old & 21.6 & Secondary School & 22.4 \\
\hline 19-28 years old & 77.3 & College & 2.0 \\
\hline 29-35 years old & .9 & University & 3.2 \\
\hline Education & & $\begin{array}{l}\text { Non Formal Knowledge } \\
\text { about Halal Food }\end{array}$ & \\
\hline Certificate & 15.3 & Books & 14.5 \\
\hline Diploma & 28.2 & Magazines & 9.8 \\
\hline Degree & 17.6 & Newspaper & 13.3 \\
\hline Others & 32.9 & Radio & 2.7 \\
\hline Origin & & Television & 5.1 \\
\hline Malaysia & 88.2 & Internet & 22.7 \\
\hline Asia & 3.5 & Family & 27.8 \\
\hline Middle East & 3.1 & Friends & 3.9 \\
\hline Europe & .4 & & \\
\hline Central Asia & 2.7 & & \\
\hline Others & 2.0 & & \\
\hline
\end{tabular}

Source: Questionnaire, Klang Valley, 1-30 April 2012.

\section{DESCRIPTIVE STATISTICS}

Table 3 presents the mean scores and standard deviations of the constructs used in this study, according to the Theory of Planned Behavior. All mean scores are presented in five point Likert scale (1-5). In general, the respondents' attitude was rated at 4.56, subjective norm at 4.03 and behavioral control at 4.12. Behavioral Intention was identified with the highest mean score at 4.97, showing that the majority of respondents' had a positive intention to consume halal food. 
The attitude was found to be the main factor of young consumers in consuming halal food. $95 \%$ of respondents agreed and strongly agreed that halal food is healthy. Thus, it could be said that the majority of the respondents had a positive attitude towards halal food. The second contributing factor was perceived as behavioral controls, which in this study specifically refers to the opportunity to consume halal food and its availability in Malaysia. This could be due to the easy access to get halal food in Malaysia.

Subjective norms were the least influential to behavioral intention to consume halal food which could be due to the characteristics of young consumers who are more independent in making decisions on their food preferences. The findings revealed that $71 \%$ of the respondents strongly disagreed and disagreed that their family influenced them to choose halal food. On the contrary, $78 \%$ of them agreed that people's perception affects their decisions to consume halal food. This data shows that the influence of friends among young consumers is stronger compared to their families in influencing them to consume halal food.

Table 3: Descriptive Statistics.

\begin{tabular}{lcc}
\hline \multicolumn{1}{c}{ Variables } & Mean & Standard Deviation \\
\hline Attitude & 4.56 & 1.32 \\
Subjective Norm & 4.03 & 2.14 \\
Behavioral Control & 4.12 & 0.99 \\
Behavioral Intention & 4.97 & 0.75 \\
\hline
\end{tabular}

*1=strongly disagree; $5=$ strongly agree

Source: Questionnaire, Klang Valley, 1-30 April 2012.

\section{CHI-SQUARE ANALYSIS}

The result of chi-square test on independence in Table 4 indicates that there is a significant relationship between selected demographic variables, namely gender and education and the behavioral intention to consume halal food. There is a significant difference between male and female consumers in their intention to choose halal food. Females are more concerned $\left(\chi^{2}=11.430\right.$, $\mathrm{p}<0.05)$ to choose halal food compared to male consumers. In terms of level of education, consumers with higher levels of education are more concerned $\left(\chi^{2}=13.110, \mathrm{p}<0.05\right)$ to consume halal food compared to the ones with lower levels of education. 
Table 4: Chi-Square Values and Respondent's Intention in Choosing Halal Food.

\begin{tabular}{ll}
\hline \multicolumn{1}{c}{ Demographic Variable } & $\chi^{2}$ \\
\hline Gender & $11.430^{*}$ \\
Level of education & $13.110^{*}$ \\
\hline
\end{tabular}

* Significant at $5 \%$ level

Source: Questionnaire, Klang Valley, 1-30 April 2012.

\section{HYPOTHESES TESTING}

The three hypotheses were tested using correlation and regression analysis and the result is presented in the Figure 2 and Table 5. The result reveals that attitude positively influences the behavioral intention in consuming halal food $\left(\beta=0.297^{* *}, p<0.01\right)$. Second independent variable, perceived behavioral control shows the significant influence $\left(\beta=0.195^{*}, p<0.05\right)$ towards behavioral intention in consuming halal food. Therefore, both hypotheses 1 and 2 are accepted. Hypothesis 3 is rejected as subjective norm and is found not significant $(\beta=0.122, p=0.147)$ on the intention in choosing halal food. The $\mathrm{R}^{2}$ of 0.77 indicates that $77 \%$ of the variation in behavioral intention in consuming halal food could be explained by the attitude and perceived behavioral control.

Figure 2: Result of Regression Analysis.

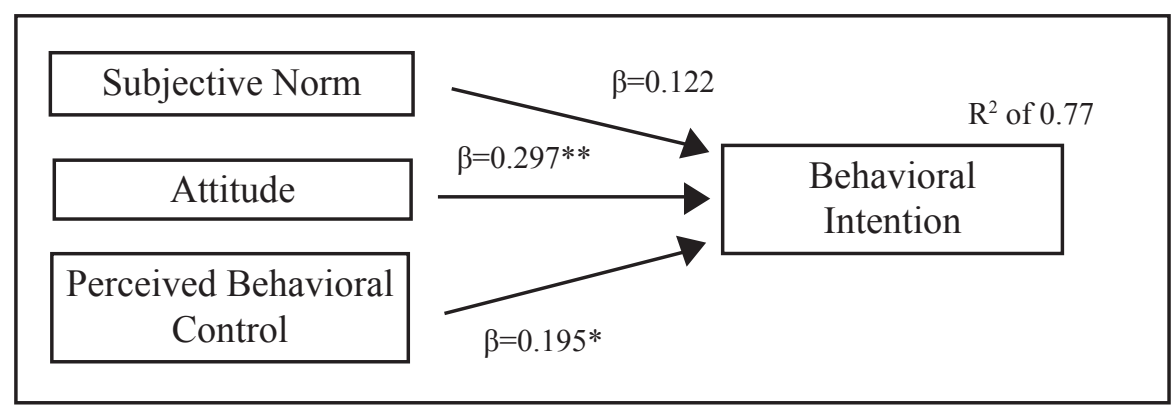

Source: Regression Analysis on the influence of attitude, subjective norms, perceived behavioral control on the behavioral intention to consume halal food, Klang Valley, 1-30 April 2012. 
Table 5: Result of Correlation Analysis.

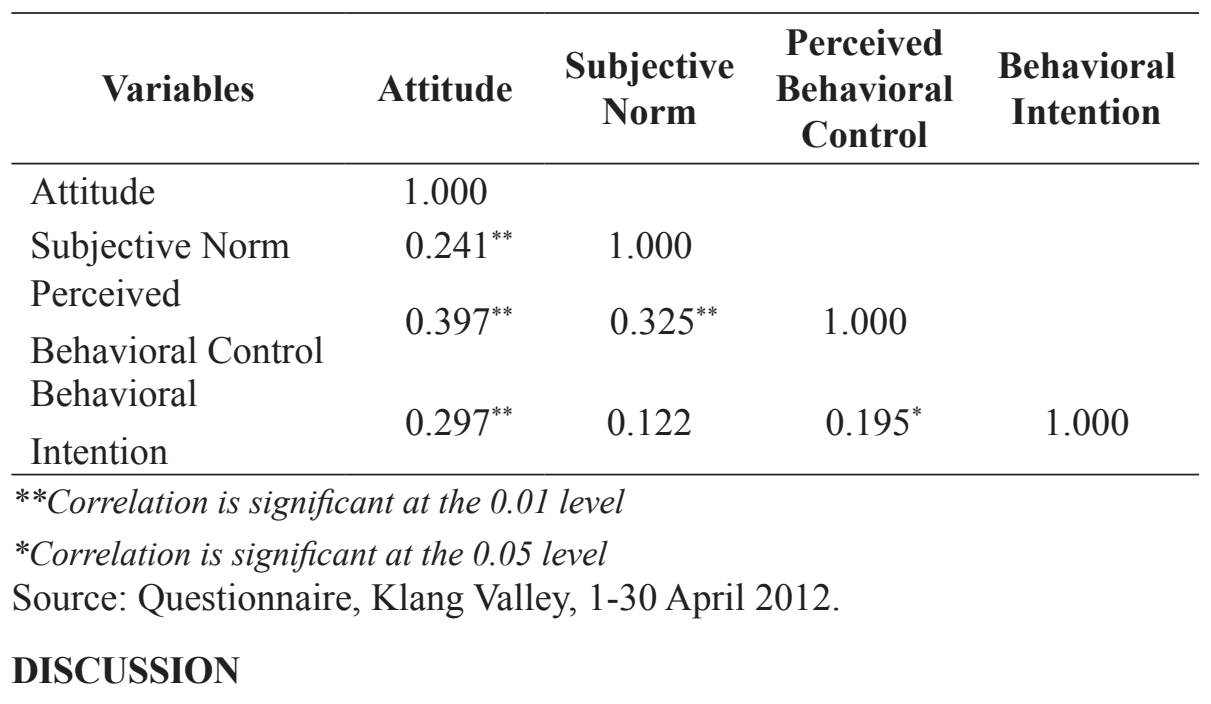

The present findings show the factors that influenced young consumers in consuming halal food are influenced by their attitude and perceived behavioral control. The results shows that positive attitude towards halal food is the most important determinant of their behavioral intention in consuming halal food. In the same vein Aitelmaalem, et al. (2005) did stress on the consumer attitude in determining the halal food consumption among Muslims. ${ }^{41}$ Similarly, Syed Shah Alam and Nazura (2011) showed that attitude was an important factor in predicting intention to consume halal food. ${ }^{42}$

Perceived behavioral control portrays a significant role in predicting consumers' intention in choosing halal food, particularly in Malaysia where halal food is easily accessible to Muslim consumers. This supports the study conducted by Bonne and Verbeke $(2007)^{43}$ and Bonne et al. (2006), ${ }^{44}$ but

${ }_{41}$ Aitelmaalem H., Breland P., Reynolds-Zayak L., 'Canadian Halal Meat Market Study,' Agriculture Food and Rural Development (2005): 22.

42 Syed Shah Alam and Nazura Mohamed Sayuti, 'Applying the Theory of Planned Behavior (TPB) in Halal Food Purchasing,' International Journal of Commerce and Management 21/1 (2011): 16.

43 Karijn Bonne, Iris Vermeir, Florence Bergeaud-Blackler, Wim Verbeke, 'Determinants of Halal Meat Consumption In France,' British Food Journal 109 (2007): 367-386.

44 Karijn Bonne and Wim Verbeke, 'Muslims Consumers Attitude Towards Meat Consumption In Belgium: Insights From A Means-End Chain Approach,' Anthropology of Food 5 (2006): 367-389. 
contradicts the findings of Syed Shah Alam and Nazura (2011) which revealed that behavioral control was not an important predictor on intention in choosing halal food..$^{45}$

Subjective norms are not found as significant in choosing halal food among young consumers in this study. Surprisingly for young consumers, family does not play an important role compared to their friends. This could be because the respondents of this study are young consumers aged between 16-35 years old living independently in the urban area of Klang Valley, and hence they are more independent in choosing food and more influenced by friends. This study confirms the findings of Liou and Contento (2001) which showed that the subjective norms did not have a positive influence on food behavioral intention. ${ }^{46}$ However, this is in contrast with the findings of Sudin Lada et al. (2006), as they revealed that subjective norm was significant where family, friends and colleagues were strong determinant points in choosing halal products in Malaysia. ${ }^{47}$ Syed Shah Alam and Nazura (2011) stressed the fact that Malaysia with a predominantly Muslim population practices collectivistic culture in which subjective norms normally play an important role for Muslims in halal food consumption. ${ }^{48}$

The practical implication of this study suggests that the government and marketers may incorporate the element of attitudes and social pressure in their halal food campaigns and advertisements. In addition, knowledge and awareness on halal food could be incorporated in the existing Islamic Studies subject at the school level for young Muslims to inculcate the positive attitude on halal food consumption.

\section{LIMITATION AND FUTURE RESEARCH}

The sample of respondents for this study was from higher learning institutions in Klang Valley. Therefore, future research may broaden the sample size and

45 Syed Shah Alam and Nazura Mohamed Sayuti, 'Applying the Theory of Planned Behavior (TPB) in Halal Food Purchasing,' 8-20.

46 Liou, D. and Contento, I.R., 'Usefulness of Psychosocial Theory of Variables in Explaining Fat-Related Dietary Behaviour in Chinese American: Association with Degree of Acculturation,' Journal of Nutrition Education 33/6 (2001): 322-331.

47 Sudin Lada, Geoffrey H. T. and Hainudin Amin, 'Predicting Intention to Choose Halal Products Using Theory of Reasoned Action,' International Journal of Islamic and Middle Eastern Finance and Management 2 (2009): 66-76.

48 Syed Shah Alam and Nazura Mohamed Sayuti, 'Applying the Theory of Planned Behavior (TPB) in Halal Food Purchasing,' 8-20. 
expand the geographical locations to other states in Malaysia. The influence of behavioral control and subjective norms towards the attitude of young consumers in choosing halal food and other products may as well be looked into in future research.

\section{CONCLUSION}

The present findings have demonstrated that the factors which influence young Muslims consumers in choosing halal food, are mainly their positive attitude towards halal food and the availability of halal food in Malaysia. It is important to note that subjective norms, particularly family do not play a significant role for young consumers to choose halal food in their daily life. The insignificant role of subjective norms contradicts with other studies which focus on Muslim consumers in general. ${ }^{49}$ This may be due to them being urban young consumers who are normally more self-determining in making the decision of their food inclination.

As Malaysia generally practices collectivistic culture, family plays a vital role in educating family members on the importance of halal food. From the behavioral perspective, government and marketers may incorporate the attitude, social pressure and behavioral control in promoting and publicizing halal food and products in Malaysia. Finally, knowing the fact that attitude is the most vital factor in determining halal food consumption, creating positive social expectation of halal products, for example the assured quality of the products, ${ }^{50}$ may possibly enhance the demand of halal food in the market.

\section{REFERENCES}

Abdul Raufu Ambali and Ahmad Naqiuddin Bakar, 'People's Awareness On Halal And Products,' Proceeding of International Halal Conference (Kuala Lumpur: Putra World Trade Centre, 11-12 September 2012).

49 Arshia, M. and Mohsin, M.B, 'Intention to Choose Halal Products: The Role of Religiosity,' Journal of Islamic Marketing 31 (2012): 1-11; Syed Shah Alam and Nazura Mohamed Sayuti, 'Applying the Theory of Planned Behavior (TPB) in Halal Food Purchasing,' 8-20; Sudin Lada, Geoffrey H. T. and Hainudin Amin, 'Predicting Intention To Choose Halal Products Using Theory of Reasoned Action,' 66-76; Karijn Bonne, Iris Vermeir, Florence Bergeaud-Blackler, Wim Verbeke, 'Determinants of Halal Meat Consumption in France' 367-386.

50 Karijn Bonne, Iris Vermeir, Florence Bergeaud-Blackler, Wim Verbeke, 'Determinants of Halal Meat Consumption in France,' British Food Journal 109 (2007): 367-386. 
Ahmad Azrin Adnan, 'Islamic Consumer Behavior (ICB): Its Why and What,' International Journal of Business and Social Science 2/21 (2011).

Aitelmaalem, H., Breland P., and Reynolds-Zayak L., 'Canadian Halal Meat Market Study,' Alberta Agriculture, Food and Rural Development (2005).

Ajzen, I. and Fishbein, 'Attitudes and the Attitude-Behavior Relation: Reasoned and Automatic Processes,' in European Review of Social Psychology, ed. Stroebe, W., Hewstone, M. (Wiley, New York: NY, 2000).

Ajzen, I., Fishbein, M., Understanding Attitude and Predicting Social Behavior (Eaglewood-Cliffs, NJ: Prentice Hall, 1991).

Ajzen, I., 'Constructing a Theory of Planned Behavior Questionnaire,' 1-7 retrieved from http://people.umass.edu/aizen/pdf/tpb.measurement.pdf, on September 9, 2011.

Anas bin Mohd Yunus, Wan Muhammad Yunus bin Wan Chik, Mahani binti Mohamad, 'The Concept of Halalan Tayyiba and Its Application in Products Marketing: A Case Study At Sabasun Hyperruncit Kuala Terengganu, Malaysia,' International Journal of Business and Social Science 1/3 (2010).

Armitage, C.J., and Conner, M., 'Efficacy of the Theory of Planned Behavior: A Meta-Analytic Review,'British Journal of Social Psychology 40 (2001).

Arshia, M. and Mohsin, M.B, 'Intention To Choose Halal Products: The Role of Religiosity,' Journal of Islamic Marketing 31/2 (2012).

Delener N., 'Religious Contrasts in Consumer Decision Behaviour Patterns: Their Dimensions and Marketing Implications,' European Journal of Marketing 28/5 (1994).

Endang S Soesilowati, 'Business Opportunities for Halal Products in the Global Market: Muslim Consumer Behaviour and Halal Food Consumption,' Journal of Indonesian Social Sciences and Humanities 3 (2010).

Golnaz, R., Zainalabidin, M., Mad Nasir, S. and Eddie Chiew, 'Non-Muslims' Awareness of Halal Principles and Related Food Products in Malaysia,' International Food Research Journal 17 (2010).

Golnaz, R., Zainalabidin, M., Mad Nasir, S. and Eddie Chiew, 'Concerns for Halal-Labeled Food Products Among Muslims Consumers in Malaysia: Evaluation of Selected Demographic Factors,' Economic and Technology Management Review 4 (2009).

Hakimah Mohd Yusoff, 'Industry Standards Committee on Halal Standards (ISCI),' Standard and Quality News 11/4 (2004). 
Karen Kueh and Boo Ho Voon, 'Culture and Service Quality Expectation Evidence from Generation Y Consumers in Malaysia,' Managing Service Quality 17/6 (2007).

Karijn Bonne, Iris Vermeir, Florence Bergeaud-Blackler, Wim Verbeke, 'Determinants of Halal Meat Consumption in France,' British Food Journal 109 (2007).

Karijn Bonne and Wim Verbeke, 'Muslims Consumers Attitude Towards Meat Consumption in Belgium: Insights from A Means-End Chain Approach,' Anthropology of Food 5 (2006).

Kristen M. Regine, Johnson, 'Generation Y Consumer Choice for Organic Foods,' Journal of Global Business Management 7/1 (2011).

Liou, D. and Contento, I.R., 'Usefulness of Psychosocial Theory of Variables in Explaining Fat-Related Dietary Behaviour in Chinese American: Association with Degree of Acculturation,' Journal of Nutrition Education 33/6 (2001).

Lutz, R.J., 'The Role of Attitude Theory in Marketing,' in Perspectives in Consumer Behavior, ed. Kassarjian, H.H. and Roberson, T.S. (Englewood: Prentice Hall, 1991).

Noorfazreen Mohd Aris and Asmak Ab Rahman, 'Perlaksanaan Dasar Sekuriti Makanan di Malaysia: Kajian daripada Perspektif Ekonomi Islam,' Shariah Journal 19/1 (2011).

Nunnally, J. C., Psychometric Theory, 2 ${ }^{\text {nd }}$ ed. (New York: McGraw-Hill, 1978).

Rushdi Ramli, 'Nilai Ibadat dalam Perbuatan-Perbuatan Harus (al-Af'āl al Mubāhah): Tinjauan Terhadap Pemikiran Imam Ahmad Ibn Taymiyyah,' Jurnal Fiqh 7 (2010).

Shahidan Shafie and Md Nor Othman, 'Halal Certification: An International Marketing Issues and Challenges,' Malaysia Standardization for Halal Food, Standard and Quality News 11/4 (2004).

Shatenstein, B. and Ghadirian, P., 'Influences on Diet, Health Behaviors and Their Outcome in Selected Ethno Cultural and Religious Group,' Nutrition 14/2 (1997).

Sparks, P. and Sheperd, R., 'Self-Identity and the Theory of Planned Behavior: Assessing The Role of Identification with Green Consumerism,' Social Psychology Quarterly 55/4 (1992).

Sudin Lada, Geoffrey H. T. and Hainudin Amin, 'Predicting Intention to Choose Halal Products Using Theory of Reasoned Action,' International Journal of Islamic and Middle Eastern Finance and Management 2/1 (2009). 
Syed Shah Alam and Nazura Mohamed Sayuti, 'Applying the Theory of Planned Behavior (TPB) in Halal Food Purchasing,' International Journal of Commerce and Management 21/1 (2011).

Van Hooft, E.A.J., Born, M.Ph., Taris, T.W. and Van der Flier, H., 'The CrossCultural Generalizability of the Theory of Planned Behavior: A Study on Job Seeking in the Netherlands,' Journal of Cross-Cultural Psychology 37/2 (2006), http://www.hdcglobal.com/publisher/, retrieved on 30 March 2013.

Wilson, J.A.J., Liu, J., 'Shaping the Halal into a Brand?' Journal of Islamic Marketing 1/2 (2010).

Wilson, J. A.J., \& Liu, J., 'The Challenges of Islamic Branding: Navigating Emotions and Halal,' Journal of Islamic Marketing 2/1 (2011).

Yūsuf al-Qaraḍāwī, al-Halāl wa al-Harām fì al-Islām, 15 $5^{\text {th }}$ ed. (Qāhirah: alMaktab al-Islāmī, 1994).

Zalina Zakaria, 'Tapping into the World Halal Market: Some Discussions on Malaysian Laws and Standard,' Shariah Journal 16 (2008).

Zul Ariff Abdul Latiff, Zainal Abidin Mohamed, Golnaz, R., Nitty Hirawaty Kararuzzaman, 'The Effect of Food Labeling Awareness on Muslim Consumers Food Purchasing Behavior in Malaysia,' Proceeding of International Halal Conference (Kuala Lumpur: Putra World Trade Centre, 11-12 September 2012). 
Jurnal Syariah, Jil. 23, Bil. 1 (2015) 79-102 